\title{
Manajemen Keuangan Pada Perusahaan Mikro Di Kabupaten Brebes
}

\author{
Ellen Rusliati' ${ }^{1}$ Mulyaningrum², Mujibah A. Sufyani ${ }^{3}$ \\ 1, 2,3 Fakultas Ekonomi dan Bisnis \\ Universitas Pasundan
}

ellenrusliati44@gmail.com, mulyaningrum.unpas@gmail.com,mujibah62@gmail.com

\begin{abstract}
ABSTRAK
Usaha mikro memberikan kontribusi dalam peningkatan kesejahteraan keluarga. Tujuan pengabdian adalah untuk meningkatkan kinerja usaha melalui manajemen keuangan. Manajemen pemasaran dan produksi senantiasa menjadi fokus utama pengusaha. Program dilakukan pada bulan Desember 2019, dengan peserta sebanyak 40 orang melalui ceramah dan diskusi pencatatan keuangan usaha sederhana. Kuesioner disebarkan untuk mengetahui karakteristik pengusaha, tipe kepemimpinan, proses digitalisasi, dan kinerja usaha. Responden yang mengisi dengan lengkap sebanyak 25. Hasilnya menunjukkan, mayoritas pengusaha belum melakukan pencatatan keuangan, omset per hari kurang dari Rp 1 juta, menggunakan modal sendiri, kepemimpinan, proses digitalisasi, dan kinerja dalam kondisi baik. Pencatatan kas menggunakan Excel diperkenalkan, namun diperlukan pendampingan berkelanjutan guna memantau implementasinya dengan materi difokuskan pada penyusunan laporan keuangan, pencatatan, dan manajemen modal kerja. Manajemen keuangan yang baik memungkinkan pengambilan keputusan yang tepat dan berdampak pada peningkatan penjualan, aset, dan keuntungan. Partisipasi Dinas Koperasi dan UMKM, perguruan tinggi, dan perusahaan besar diperlukan untuk pendampingan secara kontinu dan terintegrasi.
\end{abstract}

Kata kunci: manajemen keuangan, pelatihan, pendampingan, usaha mikro, Brebes. 


\section{PENDAHULUAN}

Persentase PDRB atas dasar harga berlaku menurut lapangan usaha di Kabupaten Brebes pada tahun 2019 terbesar adalah dari lapangan usaha pertanian, kehutanan, dan perikanan sebesar $37,26 \%$, jumlah pencari kerja sebanyak 21.781 orang dengan tingkat pendidikan sebagian besar SMA/sederajat (Statistik, 2020). Pengusaha mikro memiliki peran penting dalam menciptakan lapangan kerja, berkontribusi pada pendapatan keluarga, dan pertumbuhan ekonomi. Pemanfaatan sumber daya lokal untuk memberikan nilai tambah ekonomi diharapkan dapat meningkatkan kesejahteraan petani dan menciptakan lapangan kerja baru.

Pengusaha dapat menjadikan usahanya sehat dengan memperhatikan lingkungan internal dan eksternal. Pemilik harus sensitif, fleksibel, dan mengubah cara bertindak, dan mengambil keputusan menghadapi faktor eksternal yang dinamis jika menginginkan usahanya memiliki keunggulan bersaing yang berkelanjutan. (Osmani, 2015). Pemilik perlu mengidentifikasi dan mengurangi hambatan eksternal dan internal untuk meningkatkan daya saing usaha, walaupun upaya ini tidak dapat memecahkan masalah (Džafić et al., 2011). Analisis faktor internal meliputi misi bisnis dan analisis faktor internal dari kapasitas perusahaan. Mempertimbangkan faktor internal akan berdampak pada pertumbuhan usaha, dengan mengakui kekuatan dan menekan kelemahan (Aguilera-Castro \& Virgen-Ortiz, 2016)

Pengusaha mikro memiliki karakteristik yang timbul dari keterbatasannya, antara lain manajemen perorangan (pemilik adalah manajer), sumber (manajemen/organisasi, SDM, keuangan), pasar, dan sensitivitas pengaruh eksternal yang lebih besar. Karakteristik ini menuntut tanggung jawab pengelolaan lebih baik, karena risiko yang lebih besar, pengelolaan usaha informal dan tidak terstruktur, pragmatis, spontan, intuitif, dan terkadang reaktif. Keunggulannya adalah fleksibel, serta adaptasi, respons, dan inovasi bisnis yang cepat (Dragnić, 2014).

Keunggulan usaha perorangan menurut (Gitman, Lawrence J. and Zutter, 2015) adalah: (1) Pemilik menerima seluruh keuntungan (kerugian), (2) Biaya organisasi rendah, (3) Laba termasuk pajak pemilik, (4) Bebas, (5) Rahasia, (6) Mudah diselesaikan. Kelemahannya: (1) Pemilik mempunyai tanggung jawab tidak terbatas atas hutang, (2) kemampuan memperoleh dana yang terbatas yang dapat menghambat pertumbuhan, (3) pemilik bertanggung jawab atas seluruh transaksi, (4) Keberlanjutan terganggu ketika pemilik meninggal.

Manajemen pemasaran dan produksi menjadi fokus perhatian pengusaha untuk mendapatkan kepastian pasar dan proses produksi yang menyesuaikan dengan keinginan pasar. Manajemen SDM mengikutinya sesuai dengan kebutuhan, sedangkan manajemen keuangan cenderung diabaikan, bahkan pencatatan tidak dilakukan, akan tetapi kendala terbesar yang dihadapi untuk mengembangkan usaha adalah modal.

Fungsi manajemen keuangan menurut (Van Horne, James C; Wachowicz, John M., 2012) adalah keputusan investasi, pendanaan, dan manajemen aset. Keputusan investasi merupakan hal yang paling penting ketika ingin menciptakan nilai, yang dimulai dari penetapan total aset yang perlu dimiliki perusahaan. Pemilik perlu menetapkan jumlah yang harus muncul di dua sisi neraca, yaitu ukuran perusahaan. Setelah jumlahnya diketahui, komposisi dari aset juga diputuskan. Keputusan pendanaan menentukan komposisi sumber dana, hutang atau modal sendiri, jangka pendek atau jangka panjang. Manajemen aset berkaitan dengan pengelolaan aktiva secara efisien. Tanggung jawab ini membuat pemilik lebih memperhatikan aktiva lancar daripada aktiva tetap.

Manajemen keuangan yang berkualitas menawarkan banyak manfaat bagi pemilik, di antaranya mengetahui besarnya keuntungan, 
pengambilan keputusan lokasi pabrik, pembelian persediaan, tenaga kerja, dan mesin (Francisco, 2013). Praktik manajemen keuangan, terutama untuk arus kas dan modal kerja, yang lebih baik akan menghasilkan pengusaha mikro yang kuat dan menguntungkan (Mazzarol, Tim, 2014).

Hasil penelitian (Rugui, Lincoln and Omagwa, 2018) menunjukkan bahwa pendanaan perusahaan dan struktur kepemilikan memiliki hubungan positif yang kuat dengan kinerja, sementara manajemen kas tidak memiliki hubungan. Pengusaha di masa krisis dan globalisasi memerlukan informasi manajemen keuangan yang baik, tidak memungkinkan lagi mengelola perusahaan dengan keputusan emosional dan sesaat. Diperlukan pendidikan manajemen yang berkelanjutan untuk mengelola usaha mikro (Caliyurt, 2011). Pengelolaan manajemen keuangan yang buruk merupakan faktor utama timbulnya permasalahan bagi usaha mikro (Jindrichovska, 2014). Memahami pentingnya aktiva berwujud dan tidak berwujud bermanfaat bagi pemilik untuk pengambilan keputusan.

(Jennifer \& Dennis, 2015) menyatakan praktik manajemen keuangan (modal kerja, investasi, perencanaan keuangan, sistem informasi akuntansi, dana analisis) merupakan faktor penting yang menentukan pertumbuhan usaha kecil di Kenya. Manajemen keuangan yang tidak efisien mengakibatkan kinerja keuangan yang buruk dan kegagalan usaha. Penerapan manajemen keuangan memberikan peluang bagi usaha kecil untuk menanggapi berbagai tantangan lingkungan operasi.

Hasil penelitian (Adi et al., 2015) menunjukkan bahwa peningkatan kemampuan pengusaha mikro dapat dilakukan melalui pelatihanpelatihan teknologi produksi dan teknik budidaya organik, manajemen usaha (manajemen keuangan, pemasaran), teknologi pengolahan pangan organik, dan teknologi informasi, dengan berbagai program pelatihan secara bertahap dan berkesinambungan, dengan melibatkan secara intensif Perguruan Tinggi dan pihak BUMN/BUMD serta swasta, melalui
Program CSR/PKBL- BUMN, perbankan umum, lembaga keuangan daerah, koperasi, lembaga donor internasional, penjaminan kredit bagi UMKM, serta fasilitasi subsidi bunga dari sumber APBD kepada UMKM yang prospektif, serta mengoptimalkan perusahaan daerah (Perusda) melalui kemitraan dengan pelaku UMKM Klaster Pertanian Terpadu.

Tujuan dari pengabdian masyarakat ini adalah: (1) untuk mengetahui penerapan manajemen keuangan, (2) penentuan prioritas penerapan manajemen keuangan, dan (3) melakukan pelatihan dan pendampingan manajemen keuangan pada pengusaha mikro di Kabupaten Brebes.

\section{METODE}

Metode yang dilakukan pada pengabdian ini adalah ceramah, diskusi, dan pelatihan serta pendampingan yang dilakukan pada bulan Desember 2019 di kota Brebes kerja sama dengan Forum Komunikasi Pengusaha Muda Brebes. Pengusaha yang hadir dibatasi sebanyak maksimal 40 orang. Kuesioner disebarkan untuk mengetahui karakteristik responden, bidng usaha dan kinerjanya. Peserta yang mengisi dengan lengkap sebanyak 25 orang. Peserta yang tidak mengisi lengkap adalah sarjana yang baru lulus dan sedang belajar mencari peluang usaha yang prospektif dan mencari pengalaman dari pengusaha setempat. Materi pelatihan meliputi penyusunan laporan dan pencatatan keuangan sederhana.

\section{HASIL DAN PEMBAHASAN}

Karakteristik responden ditunjukkan pada Tabel 1.

Berdasarkan Tabel 1, tampak bahwa pengusaha milenial, pendidikan perguruan tinggi, usaha makanan, lama usaha $<5$ tahun, dengan omzet per bulan kurang dari Rp 1 juta mendominasi karakteristik responden. Karakteristik ini sebenarnya menunjukkan kekuatan potensial Kabupaten Brebes untuk mengembangkan usaha mikro dengan menggunakan bahan lokal. Produk yang dihasilkan kebanyakan adalah makanan dengan memanfaatkan hasil pertanian/peternakan yang dihasilkan, antara 
lain kacang tanah, keripik singkong/pisang, dan produk unggulan Kab. Brebes adalah telur asin dan bawang merah. Produk dijual di pasar setempat dengan mengikuti harga pasar.

Kinerja usaha mengalami peningkatan ditunjukkan pada Tabel 2.

Tabel 2

Kinerja usaha

\begin{tabular}{llc}
\hline No & Ukuran Kinerja & Skor Rata-rata \\
\hline 1 & Penjualan & 3,68 \\
2 & Keuntungan & 3,52 \\
3 & Modal & 3,20 \\
4 & Daerah Pemasaran & 3,68 \\
5 & Daya saing produk & 3,60 \\
6 & Proses produksi & 3,36 \\
7 & Kualitas produk & 3,68 \\
8 & Jumlah produk & 3,68 \\
9 & Kemampuan karyawan & 3,24 \\
10 & Kreativitas karyawan & 3,24 \\
11 & Jumlah tenaga kerja & 3,24 \\
\hline Rata-rata & 3,47 \\
\hline
\end{tabular}

Tabel 2 menunjukkan rata-rata kinerja dalam kategori baik artinya mengalami peningkatan, yang berada di bawah rata-rata adalah modal, proses produksi, kemampuan dan kreativitas karyawan, serta jumlah tenaga kerja. Artinya usaha yang dijalankan belum diikuti dengan adanya peningkatan ukuran kinerja ini. Modal merupakan ukuran kinerja yang paling rendah, karena hanya mengandalkan modal sendiri. Pencatatan keuangan yang tidak memadai, tidak mendukung pengusaha untuk meningkatkan modal memanfaatkan sumber eksternal, seperti modal pinjaman demikian pula halnya penyertaan.
Pencatatan keuangan tidak dilakukan, karena pada prinsipnya usaha yang dilakukan untuk memenuhi kebutuhan keluarga. Keuangan digabungkan antara kebutuhan keluarga dan usaha. Hasil ini senada dengan hasil penelitian (Bismala, 2016) bahwa pengusaha mikro belum melakukan pembukuan karena mengalami kesulitan dan memerlukan ketelitian, sedangkan pengusaha belum memiliki pengetahuan dan disiplin yang memadai untuk melakukan pencatatan. Hal ini menyebabkan pengusaha mengalami kesulitan ketika akan melakukan penambahan modal. Modal sendiri terbatas, di lain pihak melakukan pinjaman ke bank tidak memenuhi syarat tuntutan adanya laporan keuangan yang lengkap dengan tujuan untuk menilai kelayakan pemberian kredit, meyakinkan bahwa kredit digunakan sesuai dengan pengajuan, dan mengukur kemampuan untuk mengembalikannya.

Penting sekali memisahkan keuangan keluarga dengan usaha, sehingga dapat mengukur keuntungan/kerugian yang diperoleh. Selanjutnya pencatatan keluar masuk kas usaha. Perubahan ini memerlukan waktu yang lama, karena menyangkut kebiasaan dan kedisiplinan. Pencatatan kas secara sederhana atas setiap transaksi penerimaan dan pengeluaran kas, dapat menggunakan Excel. Hal yang sama juga dilakukan untuk mencatat hutang dan piutang.

Fungsi manajemen keuangan adalah untuk keputusan investasi, pendanaan, dan manajemen aktiva (Gitman, Lawrence J. and Zutter, 2015) belum diterapkan pada usaha mikro di Kab, Brebes. Keputusan investasi berhubungan dengan penentuan besarnya aktiva yang dimiliki, serta komposisinya. Usaha mikro lebih penting mengelola modal kerjanya, meliputi kas, piutang, dan persediaan. Sumber dana yang terbatas, karena hanya menggunakan modal sendiri sedapat mungkin digunakan secara efisien dan efektif. Pengadaan bahan baku dapat menggunakan kredit dari penjual, sehingga dana yang tersedia dapat digunakan untuk membiayai operasi dan aktiva lancar lainnya yang 
tidak memungkinkan mendapatkan kredit dari penjual.

Pertumbuhan usaha sering kali menuntut adanya peningkatan kebutuhan dana, artinya melakukan ekspansi, yang terdiri dari dua jenis yaitu berangsur-angsur dan melonjak. Hal utama yang perlu diidentifikasi adalah pemanfaatan dana artinya keputusan investasi pada aktiva lancar atau aktiva tetap, besarnya ekspansi, selanjutnya sumber dana yang akan diakses. Prinsip maturity matching diperlukan agar tidak terjadi masalah, yaitu kebutuhan jangka pendek menggunakan sumber dana jangka pendek demikian pula halnya kebutuhan jangka panjang. Kebutuhan jangka panjang sangat tidak dibenarkan menggunakan sumber dana jangka pendek, karena dikhawatirkan akan mengganggu likuiditas, yaitu ketika hutang sudah jatuh tempo sedangkan dana masih tertanam pada aktiva tetap, yang akan kembali secara berangsur-angsur melalui penyusutan.

Peningkatan penjualan dapat dilakukan dengan menjual secara kredit, namun perlu memperhatikan risiko, berupa investasi pada piutang dan piutang tidak tertagih. Penjualan kredit dimulai dari seleksi pelanggan dan penentuan besarnya kredit serta jangka waktunya. Hal ini perlu dipahami, karena penjualan secara kredit akan mengakibatkan dana yang diinvestasikan pada piutang menjadi lebih tinggi, sehingga menekan kas tersedia, dan memerlukan modal yang lebih besar.

Persediaan bahan baku, barang dalam proses, dan barang jadi diusahakan dalam jumlah yang minimal, sehingga dapat menekan kebutuhan dana. Sama halnya dengan piutang, investasi pada persediaan yang terlalu tinggi juga mengakibatkan dana yang dibutuhkan tinggi. Penentuan besarnya persediaan dapat dilakukan berdasarkan pengalaman, walaupun demikian pendekatan persediaan nol (zero inventory approach) dapat diterapkan secara hati-hati agar tidak mengganggu proses produksi dan penjualan.

Aktiva tetap sebaiknya menggunakan fasilitas yang dimiliki di rumah, kecuali peralatan tersebut memang tidak ada. Keputusan pembelian aktiva tetap, perlu dihitung kelayakannya, yaitu kemampuan aktiva tetap tersebut dapat meningkatkan penjualan atau mengurangi biaya, aliran kas, serta tingkat pengembalian yang diharapkan. Selanjutnya sumber dana untuk memenuhi kebutuhan aktiva tetap juga perlu dipertimbangkan. Penggunaan modal sendiri adalah sumber dana yang aman, karena tidak ada beban bunga dan jangka waktu pengembalian, namun sering kali jumlahnya terbatas bahkan tidak tersedia. Penggunaan modal pinjaman dengan mengakses lembaga keuangan harus dilakukan secara hati-hati dengan memperhatikan jangka waktu aktiva tetap yang dibutuhkan.

Sangat penting bagi usaha mikro memelihara likuiditasnya, sehingga terhindar dari tagihan yang tidak terbayar dan kepercayaan dari pemasok terganggu. Upaya yang dapat dilakukan adalah menyusun anggaran kas, hutang, dan piutang. Anggaran kas berfungsi untuk mengetahui posisi kas di masa yang akan datang, apakah surplus atau defisit. Anggaran hutang dan piutang dimaksudkan untuk mengetahui berapa, kapan, dan kepada siapa harus membayar dan menagih.

Tahapan selanjutnya adalah menyusun laporan laba rugi, dengan mengelompokkan penerimaan yang berasal dari penjualan (baik tunai maupun kredit) mengurangkannya dengan biaya produksi dan biaya operasi, sehingga terukur laba/rugi yang diperoleh. Keuntungan yang diperoleh perlu dibandingkan dengan total aktiva yang digunakan untuk operasi perusahaan, guna mengetahui kemampuan atas aktiva yang dimiliki menghasilkan keuntungan (profitabilitas). Pengukuran ini dimaksudkan untuk mengukur kemampuan usaha memberikan keuntungan.

Kesulitan memperoleh pinjaman dari lembaga keuangan merupakan salah satu dari sekian banyak faktor yang menghambat pertumbuhan usaha mikro (Yuwono \& Retno, 2013). Hal ini disebabkan tidak adanya laporan keuangan dan proyeksi arus kas atas penggunaan kredit yang diajukan, sebagai salah 
satu syarat yang harus dipenuhi. Perbankan harus menjalankan prinsip hati-hati dalam menyalurkan kredit. Lembaga keuangan yang dapat diakses adalah pegadaian atau lembaga keuangan berbasis teknologi (fintech) yang melakukan ekspansi kredit secara agresif.

Prinsip hati-hati juga perlu dimiliki pengusaha ketika menghadapi tawaran kredit yang terasa memudahkan. Pengusaha harus memiliki keyakinan bahwa kredit dimanfaatkan untuk usaha. Penggunaan hutang akan mendukung pertumbuhan usaha, namun risiko meningkat yaitu kewajiban membayar bunga dan mengembalikan kredit pada waktunya. Keputusan harus diawali dengan penentuan besarnya dana yang diperlukan, maturity matching, kemudian dilakukan proyeksi arus kas yang memperhitungkan besarnya pendapatan dan keuntungan yang akan diperoleh atas penggunaan kredit. Prinsipnya yaitu tingkat pengembalian yang diperoleh harus lebih besar dari tingkat suku bunga yang harus dibayar. Lembaga keuangan yang berbasis bagi hasil sebenarnya lebih aman, karena berpatokan pada keuntungan bukan dari pokok pinjaman.

Analisis kredit juga perlu dilakukan dengan membandingkan modal sendiri dengan jumlah hutang, selanjutnya kemampuan membayar hutang beserta bunganya. Upaya yang dilakukan untuk mengantisipasinya adalah menyusun proyeksi neraca, laporan laba rugi, dan anggaran kas. Hal ini dimaksudkan untuk menghindarkan perusahaan dari posisi illikuid yang dapat mengakibatkan kebangkrutan, bahkan aset pengusaha dapat disita karena tanggung jawabnya sampai dengan ke aset pemilik usaha.

Sumber dana lain yang juga memungkinkan untuk diakses adalah penyertaan, dengan konsekuensi berbagi kepemilikan. Hasil penelitian (Rugui, Lincoln and Omagwa, 2018) menunjukkan bahwa pendanaan perusahaan dan struktur kepemilikan memiliki hubungan positif yang kuat dengan kinerja. Prinsip hati-hati tetap perlu dilakukan, karena rawan terjadi konflik. Surat perjanjian yang mengikat di antara pemilik, mengenai posisi modal, pembagian keuntungan, dan kewenangan pengambil keputusan.

Manajemen aktiva menuntut pemanfaatan aset yang dimiliki secara efisien dan efektif dalam rangka menjalankan usaha guna menghasilkan keuntungan. Aktiva tetap yang dimiliki pengusaha dapat digunakan untuk operasi perusahaan dengan bebas biaya, untuk sementara waktu. Jika usaha tumbuh dengan baik, maka dapat saja aktiva tetap yang digunakan usaha dikenakan biaya sewa dengan mengikuti harga pasar. Pemanfaatan aktiva harus dilakukan secara efisien dan efektif, dalam rangka mencapai keuntungan yang diharapkan sesuai dengan tujuan perusahaan. Keuntungan bersifat relatif, sehingga yang lebih tepat adalah profitabilitas, yaitu kemampuan atas aktiva yang dimiliki untuk menghasilkan keuntungan. Rasio ini kemudian dibandingkan dengan tingkat pengembalian bebas risiko, yang paling mudah adalah tingkat suku bunga deposito.

Peningkatan kemampuan pengusaha mikro di Kab. Brebes dimungkinkan melihat potensi yang dimiliki dengan pendampingan dari instansi terkait (Adi et al., 2015). Pelatihan dan pendampingan dapat dilakukan dengan melihat urutan prioritas yang diperlukan pengusaha, serta progres dari penerapannya. Hal yang sama juga dikemukakan oleh (Caliyurt, 2011). Hal ini dapat dipahami untuk senantiasa memantau konsistensi hasil pelatihan dan pendampingan. Praktik manajemen keuangan yang benar akan mempengaruhi pertumbuhan usaha kecil (Jennifer \& Dennis, 2015).

Pengusaha perlu melakukan perubahan pola pikir, bisnis harus dilakukan secara serius dengan memanfaatkan ilmu yang dapat dipelajari dari berbagai sumber. Penentuan misi, analisis faktor internal dan eksternal perlu dilakukan untuk mengetahui potensi dan peluang yang dimiliki, agar 
pengambilan keputusan tidak keliru (Aguilera-Castro \& Virgen-Ortiz, 2016). Pengambilan keputusan yang tidak tepat dapat membawa usaha ke arah yang salah, bahkan dapat mengakibatkan kebangkrutan. Hal ini senada dengan hasil penelitian (Mazzarol, Tim, 2014) bahwa manajemen keuangan yang baik terutama arus kas dan modal kerja akan menghasilkan pengusaha mikro yang menguntungkan.

\section{KESIMPULAN}

Kesimpulan kegiatan pengabdian pada masyarakat ini adalah pengusaha mikro di Kab. Brebes potensial untuk senantiasa diberikan kesempatan untuk mengikuti pelatihan dan pendampingan dalam menjalankan usaha dalam rangka peningkatan kinerja. Manajemen keuangan merupakan salah satu topik yang perlu diberikan dalam program tersebut, dengan prioritas arus kas, modal kerja, dan penyusunan laporan laba rugi dan neraca. Modal sendiri adalah sumber dana aman, namun tersedia dalam jumlah yang terbatas, sehingga menghambat pertumbuhan usaha. Penggunaan modal pinjaman pada lembaga keuangan menuntut pemahaman yang baik tentang manajemen keuangan, karena meningkatkan risiko.

\section{DAFTAR PUSTAKA}

Adi, R. K., Harisudin, M., \& Ferichani, M. (2015). Analisis Faktor-Faktor Penentu Keberhasilan Klaster (Studi Pada Klaster Pertanian Terpadu Kabupaten Sukoharjo). Caraka Tani: Journal of Sustainable Agriculture, 30(2), 81. https://doi.org/10.20961/carakatani.v30i2.119 22

Aguilera-Castro, A., \& Virgen-Ortiz, V. (2016). Model for developing strategies specific to sme business growth. Entramado, 13(2), 30-40. https://doi.org/10.18041/entramado.2016v12n 2.24204
Bismala, L. (2016). Model Manajemen Usaha Mikro Kecil dan Menengah (UMKM) untuk Meningkatkan Efektivitas Usaha Kecil Menengah. Jurnal Enterpreuner Dan Enterpreneurship, 5(1), 19-25.

Caliyurt, T. (2011). Importance Of Financial Management Knowledge in Small and Medium Enterprises ( SMEs ) Managing by Women. Journal of Social Science, 2, 327-354.

Dragnić, D. (2014). Impact of internal and external factors on the performance of fast-growing small and meduim businesses. Management (Croatia), 19(1), 119-159.

Džafić, Z., Zahirović, S., Okičić, J., \& Kožarić, A. (2011). Internal and external obstacles to the development of SMEs in Bosnia and Herzegovina. Croatian Economic Survey, 13(1), 143-171.

Francisco, A. (2013). Financial Management for Small Business. https://www.sba.gov/sites/default/files/files/P ARTICIPANT_GUIDE_FINANCIAL_MAN AGEMENT.pdf

Gitman, Lawrence J. and Zutter, C. J. (2015). Principle of Management Finance (Fourteen). Pearson Education Limited.

Jennifer, K. M., \& Dennis, O. (2015). Financial Management Practices on growth of Small and Medium Enterprises: A case of Manufacturing Enterprises in Nairobi County. IOSR Journal of Business and ManagementVer. II, 17(8), 23197668. https://doi.org/10.9790/487X-17826577

Jindrichovska, I. (2014). Financial management in SMEs. European Research Studies Journal, 16(4), 79-95. https://doi.org/10.35808/ersj/405

Mazzarol, Tim. (2014). the Challenge of Financial Management in Smes. 21(1), 2-13.

Osmani, E. (2015). IMPORTANCE OF EXTERNAL AND INTERNAL ENVIRONMENT IN CREATION OF COMPETITIVE ADVANTAGE TO SMES. (CASE OF SMEs, IN THE NORTHERN REGION OF ALBANIA). European Scientific Journal, 11(13), 120-130. https://doi.org/10.19044/esj.2015.v11n13p\%p

Rugui, Lincoln and Omagwa, J. (2018). Effect of Financial Management Practices on 
Performance of Selected Small and Medium Enterprises in Limuru Town, Kenya. International Journal of Scientific and Education Research, 2(05), 51. https://doi.org/10.18843/ijms/v5i4(8)/06

Statistik, B. P. (2020). Kabupaten Brebes Dalam Angka.

https://brebeskab.bps.go.id/publication/downlo ad.html?nrbvfeve=ZDNmNDM3N2ViNjNIN WVkZDkzY2I2MjE3\&xzmn=aHR0cHM6Ly 9icmViZXNrYWIuYnBzLmdvLmlkL3B1Ym xpY2F0aW9uLzIwMjAvMDQvMjcvZDNmN DM3N2ViNjNINWVkZDkzY2I2MjE3L2thY nVwYXRlbilicmViZXMtZGFsYW0tYW5na 2EtMjAyMC5odG1s\&t

Van Horne, James C; Wachowicz, John M., J. alih bahasa Q. M. (2012). Prinsip-prinsip Manajemen Keuangan (13. Buku I). Salemba Empat.

Yuwono, R., \& Retno, R. R. (2013). Analisa FaktorFaktor Penghambat Pertumbuhan Di Jawa Timur. Agora, 1(3).

Tabel 1

Karakteristik Responden

\begin{tabular}{lllll}
\hline No & \multicolumn{1}{c}{ Karakteristik } & & \\
\hline 1 & Jenis Kelamin & Perempuan $=52 \%$ & Laki-laki $=48 \%$ & \\
2 & Usia & $<21=16 \%$ & $21-37=48 \%$ & $>37$ tahun $=34 \%$ \\
3 & Tingkat pendidikan & SD, SMP $=8 \%$ & SMA $=44 \%$ & PT $=48 \%$ \\
4 & Bidang Usaha & Makanan $=72 \%$ & $\begin{array}{l}\text { Manufaktur bukan } \\
\text { makanan }=20 \%\end{array}$ & Dagang $=8 \%$ \\
5 & Lama Usaha & $<5$ tahun $=78 \%$ & $>5$ tahun $=32 \%$ & \\
6 & Omzet per bulan & $<$ Rp 1 juta $=76 \%$ & $\begin{array}{l}\text { Rp 1 juta }- \text { Rp 20 } \\
\text { juta }=24 \%\end{array}$ & $>$ Rp 20 juta $=0 \%$ \\
\hline
\end{tabular}

